Transportation Research Forum

Book Review: Competition in the Railway Industry: An International Comparative Analysis

Book Author(s): José Gómez-Ibáñez and Ginés de Rus

Review Author(s): Stephen J. Thompson

Source: Journal of the Transportation Research Forum, Vol. 46, No. 2 (Summer 2007), pp.133-135

Published by: Transportation Research Forum

Stable URL: http://www.trforum.org/journal

The Transportation Research Forum, founded in 1958, is an independent, nonprofit organization of transportation professionals who conduct, use, and benefit from research. Its purpose is to provide an impartial meeting ground for carriers, shippers, government officials, consultants, university researchers, suppliers, and others seeking exchange of information and ideas related to both passenger and freight transportation. More information on the Transportation Research Forum can be found on the Web at www.trforum.org. 
Gómez-Ibáñez, José, and de Rus, Ginés, eds. Competition in the Railway Industry: An International Comparative Analysis. Cheltenham, UK, and Northamption, MA, USA: Edward Elgar Publishing, Inc., 2006. ISBN 1845429036.

\title{
Competition in the Railway Industry
}

\author{
by Stephen J. Thompson
}

The book is a result of an international conference at Madrid, Spain, in September 2004. The conference and the book were financially supported by the Rafael del Pino Foundation. The book is a collection of essays written and edited by well-recognized transport analysts in Europe, Latin America, and the United States. The book is part of a series on transport economics, management and policy. A separate chapter is devoted to each of the following countries: Britain, France, Spain and the United States. One chapter discusses Latin America, with particular reference to Argentina, Brazil and Mexico. These five chapters have footnotes and references. In addition to the seven countries named above, many countries receive some attention, or at least passing reference, including Australia, Canada, Chile, Germany, Japan, New Zealand, Norway, Peru, Sweden and Uruguay. (See, for example, the table on page 83.) The book has two introductory pieces, and a concluding chapter entitled "The prospects for competition." Only the chapter on the United States offers crisp, unqualified suggestions for further changes in public policy. Throughout the rest of the book, only tentative or relatively better approaches are identified and compared to alternatives, and these approaches generally are couched in caveats and qualifying comments. This last sentence is not intended as a criticism, as will become clearer at the end of this review.

\section{EXPERIENCE WITH RAIL REFORM}

Before 1980, most railroads were government-owned in the countries discussed in the book, except for railroads in the United States and one of the two transcontinental railroads in Canada. A single company typically provided the track and related facilities, as well as the train service over those tracks and related facilities. By 1980, as a result of increasing competition from other modes of transportation, government-owned railroads were a huge drain on their national treasuries, and in Canada and the United States, privately-owned railroads were facing the possibility of nationalization because of their precarious financial health. A wave of rail reform in the countries treated in the book began with the enactment of the Staggers Rail Act of 1980 in the United States. These reforms were intended to improve rail service, attract more traffic from competing modes of transport, and improve the financial performance of railroads.

In Britain, passenger traffic is a much bigger share of rail traffic than freight. Freight can often be transported by water or truck. Privatization legislation was enacted in Britain in 1993. The original concept was to have privately-owned companies compete for 25 contracts. One privatelyowned company, operated as a regulated monopoly, was to provide track and related facilities. Largely as a result of cost overruns for track and related facilities and missteps by government, the track company entered bankruptcy, and the provision of passenger service did not greatly improve. In Britain, "both the new infrastructure company, Network Rail, and the TOCs (train operating companies) now sit precariously on an indistinct boundary between public and private sectors with foggy corporate objectives and ill-defined duties toward the public interest." (page 78) 
In France, passenger traffic is a much bigger share of rail traffic than freight. France has a highspeed passenger train service, named the TGV, that connects many cities in France and connects with adjacent countries. France began reforms in the 1980s. France had a single, integrated rail firm, the Société Nationale des Chemins de Fer Français, or SNCF, until 1997. In 1997, France created a public undertaking named Réseau Ferré de France, or RFF, that is responsible for track and related facilities. With one exception, the regions of France negotiate contracts with SNCF for services. "In some respects the prospects for competition appear dim.... Nevertheless, there are some market segments where entry seems likely.” (page 102)

In Spain, "RENFE (Red Nacional de Ferrocarriles) was born in 1941 to rescue the existing private operators from the ashes of the Spanish Civil War (1936-1939) and remained the uncontested provider of rail services for over 60 years." (page 111) "Rail dominated transport in Spain until the 1960s, when competition from other modes started to sharply erode its position." (page 111) Spain began reforms in 1984 through the use of management contracts. A law in 1987 "revoked the modal preference for rail transport and promoted instead competition among all modes." (page 114) In 1997, a public body, named the Rail Infrastructure Manager (Gestor de Infrastructuras Ferroviarias, or GIF), was created to provide track and related facilities. Spain has discontinued the use of management contracts to achieve rail reform.

In Argentina, traffic declined rapidly beginning in the 1960s. The railroads employed too many people and continued to operate unprofitable lines. For freight, the government let six concessions for 30-year terms with the possibility of renewals. For intercity passenger services, only one route was potentially profitable. With the economic deterioration in Argentina starting early in 1999, the government did not meet its commitment to make subsidy payments on commuter concessions. The defaults in payments resulted in contract renegotiations.

In Brazil, the railroads suffered during the national economic crisis from 1982 to 1992, and only $60 \%$ of government rail funding went to support the public rail transport system, the rest went to a specialized line serving a steel company. Two non-mining railroads comprised more than $90 \%$ of Brazil's rail network. The two non-mining railroads were divided into seven separate concessions, each for 30 years with the possibility of an extension for another 30 years. One railroad was used to hold old rail debts and to hold title to rail tracks and related facilities.

Mexico has three major industrial areas, and major ports on the Pacific Ocean and on the Caribbean Sea. Before Mexico began its post-1980 rail reform, it had only one railroad which was government-owned. Mexico now has three privately-owned railroads: one leading south from Mexico City, and two leading north, each connecting with a different U.S. railroad. Each of the three railroads serves a major port on the Pacific Ocean and on the Caribbean Sea. Mexico City is served by all three railroads through a terminal railroad that the three railroads own. Both of the other two major industrial areas are served by two railroads and each of these railroads has access to customers in the two industrial areas through exchange of trackage rights, although the required access rights are strictly limited to a few locations. Railroads are expected to negotiate access charges and terms of the trackage rights. The Secretary of Transport is empowered to set access charges and terms of these trackage rights if the railroads cannot agree.

Canada has promoted competition among railroads since the early 1900s by allowing a rail customer to have access to a second railroad when that second railroad is located within 30 kilometers of the rail customer at either the origin or destination of a shipment. In 1987, Canada began to promote more competition among railroads. Canada did this by eliminating rail collective ratemaking, by allowing confidential contracts between rail carriers and their customers, and by introducing best-and-final offer arbitration when a rail carrier and customer reach an impasse in setting a rate. In 1995, Canada sold the publicly-owned Canadian National Railway to the private sector. The other transcontinental Canadian railroad, the Canadian Pacific, was already privatelyowned. 
The United States separated rail passenger service from rail freight service beginning in 1971 with the creation of Amtrak. A major objective in creating Amtrak was to improve the financial health of freight railroads. The Staggers Rail Act of 1980 partially deregulated railroad rates and services, and reduced antitrust immunity for railroads to set rates collectively. The 1980 Act allowed railroads to restrict many routing options by rail customers which would result in interlining traffic between two or more railroads and thus were being used by rail customers to promote competition among railroads. The 1980 Act allowed confidential contracts for rail transportation services, and relaxed restrictions on rail mergers and on rail line abandonments. The 1980 Act allowed the Interstate Commerce Commission (which later became the Surface Transportation Board) to exempt some rail traffic from economic regulation, and provided that the Board should oversee rail rates on "market dominant" traffic. Following enactment of the 1980 Act, rail productivity has improved, costs to railroads to produce transportation have declined, and prices charged every major category of rail freight traffic have declined.

\section{SUGGESTIONS FOR FURTHER RESEARCH}

The book provides public policy analysts and policy makers with a good benchmark regarding the progress to date of various countries in promoting competition among railroads, increasing rail traffic, and strengthening the financial position of railroads. Perhaps we will have the good fortune to see a follow-on study soon, perhaps funded by a public-interest foundation, and utilizing the skills of well-qualified rail analysts from Europe, America, and Australia. (The Australian experience might by then provide some interesting and helpful insights into promoting competition among railroads because Australia has begun a strong program to promote competition among railroads.) Perhaps by the time that book is written, the policy options will be clearer regarding rail transport in countries where railroads are still owned by the government, such as France and Spain.

Public policy analysts and policy makers, particularly in the United States, probably would be well served by such a study if the study includes a separate chapter or two on each of the following countries: Canada, the United States, Mexico, and Australia. The reason is that rail conditions and public policies in Canada and Mexico are more like the United States than are Britain, Spain, France, Argentina and Brazil. The study likely would be stronger and more helpful than the book reviewed here if a variety of future public policy options available to Canada, the United States, Mexico and Australia are written and discussed by more than one analyst regarding each of those countries, so that a variety of viewpoints will be presented and analyzed.

Stephen $\mathbf{J}$ Thompson has a B.S. in accounting and an M.S. and Ph.D. in economics. He has taught public policy toward business at two universities, been a transportation economist at the Surface Transportation Board (when it was still the Interstate Commerce Commission), and been a specialist in transportation at the Congressional Research Service, which is a division of the Library of Congress. 